\title{
Pyridine Nucleotide-Dependent Superoxide Production by a Cell-Free System from Human Granulocytes
}

\author{
Bernard M. Babior, John T. Curnutte, and Ruby S. Kipnes \\ From the Department of Medicine, Tufts-New England Medical Center, \\ Boston, Massachusetts 02111
}

A в S TRACT Using an assay that measured superoxide dismutase-inhibitable nitro blue tetrazolium reduction, we studied superoxide $\left(\mathrm{O}_{2}^{-}\right)$production by a cell-free system from human granulocytes. At $40 \mu \mathrm{M}$ NADPH and a protein concentration of $0.12 \mathrm{mg} / \mathrm{ml}$, lysates prepared from human granulocytes formed $\mathrm{O}_{2}{ }^{-}$ at a rate of $18.4 \pm 4.6 \mathrm{SE} \mathrm{nmol} / \mathrm{ml}$ reaction mixture per h. $\mathrm{O}_{3}^{-}$was also produced with $\mathrm{NADH}$ as electron donor, but not with glucose-6-phosphate, 6-phosphogluconate, glyceraldehyde-3-phosphate, sodium lactate, glutathione, or ascorbic acid. The $K m$ 's for NADPH and $\mathrm{NADH}$ were $8.6 \pm 4.6 \mu \mathrm{M}$ and $0.83 \pm 0.30 \mathrm{mM}$, respectively, suggesting that $\mathrm{NADPH}$ is the physiological electron donor in this system. $\mathrm{O}_{2}^{-}$production was not inhibited by $1 \mathrm{mM} \mathrm{KCN}$. The rate of $\mathrm{O}_{2}^{-}$production by the cell-free system was comparable to the rate of $\mathrm{O}_{2}^{-}$ production by an equivalent quantity of intact granulocytes incubated under similar conditions. $\mathrm{O}_{2}^{-}$production by lysates from granulocytes preincubated with serum under conditions previously shown to stimulate $\mathrm{O}_{2}^{-}$ production in the intact cells was no different than its production by lysates from unstimulated cells.

$\mathrm{O}_{3}^{-}$production at $0.2 \mathrm{mM}$ and $0.02 \mathrm{mM}$ NADPH by lysates from the granulocytes of two patients with chronic granulomatous disease was similar to $\mathrm{O}_{2}^{-}$production by control lysates. This finding was interpreted in terms of the possibility that the metabolic lesion in chronic granulomatous disease may lie outside the oxygen-metabolizing enzyme system of the granulocyte, or alternatively, that the granulocytes may contain two $\mathrm{O}_{2}$-forming enzymes, one of which is inactive in chronic granulomatous disease.

\section{INTRODUCTION}

The uptake of particles by granulocytes is accompanied by alterations in oxygen metabolism (the "respiratory burst") that are related to the activation of certain bac-

Receized for publication 16 January 1975 and in reaised form 27 May 1975. tericidal processes within the cell (1-7). Several lines of evidence suggest that an increase in superoxide $\left(\mathrm{O}_{2}^{-}\right)$ production is one feature of the respiratory burst. These lines of evidence include the finding that large quantities of $\mathrm{O}_{2}^{-}$are produced by granulocytes exposed to bacteria and serum $(8-10)$, the observation that granulocytes from patients with chronic granulomatous disease $(\mathrm{CGD})^{1}$ fail to produce $\mathrm{O}_{2}^{-}$(11), and the demonstration that $\mathrm{O}_{2}^{-}$-generating systems are able to destroy microorganisms in vitro [in some cases through the action of the $\mathrm{H}_{2} \mathrm{O}_{2}$ produced by the spontaneous dismutation of $\mathrm{O}_{2}^{-}$(12) and in other cases by means of the product of a reaction between $\mathrm{O}_{2}^{-}$and $\mathrm{H}_{2} \mathrm{O}_{2}(13$, 14)].

The production of $\mathrm{O}_{2}^{-}$by a cell-free system from granulocytes was first reported by Johnston et al. (15) and later confirmed by Allen et al. (16). Their experiments showed that a portion of the dye reduction occurring when these systems were incubated with nitro blue tetrazolium (NBT) and a pyridine nucleotide was abolished by superoxide dismutase. Characterization of this $\mathrm{O}_{3}^{-}$-forming process, however, has not been undertake to date. It is the purpose of this report to describe some of the features of $\mathrm{O}_{2}^{-}$production by a cellfree system from granulocytes.

\section{METHODS}

Dextran $70,6 \%$ in $0.9 \%$ saline (Macrodex ${ }^{\circledR}$ ), was obtained from Pharmacia Laboratories Inc., Piscataway, N. J. Hanks' buffered saline solution (HBSS), $1 \times$ concentrated without phenol red, was purchased from Grand Island Biological Co., Grand Island, N. Y. Escherichia coli C was the generous gift of Dr. Andrew Wright. E. coli 0111:B4 (ATCC 12015) was purchased from the American Type Culture Collection, Rockville, Md. NBT, pyridine nucleotides (preweighed vials), glucose-6-phosphate, 6-phosphogluconic acid, glyceraldehyde-3-phosphate, sodium lactate, glutathione, ascorbic acid, cytochrome $c$ (type VI), xanthine oxidase (grade I), and bovine serum albumin were

${ }^{1}$ Abbreviations used in this paper: CGD, chronic granulomatous disease; HBSS, Hanks' buffered saline solution; NBT, nitro blue tetrazolium. 
obtained from Sigma Chemical Co., St. Louis, Mo. Superoxide dismutase from bovine erythrocytes was purchased from Truett Laboratories, Dallas, Tex. Absolute ethanol was obtained from U. S. Industrial Chemical Co., New York. Other reagents were the best grade commercially available and were used without further purification.

Granulocytes and granulocyte lysates. Human granulocytes from $50-100 \mathrm{ml}$ of blood were prepared as described elsewhere (8). The cells were suspended in HBSS and counted in a hemacytometer. To prepare granulocyte lysates, the cells were pelleted by centrifugation at $1,000 \mathrm{rpm}$ for 4 min, resuspended in $1.3-1.8 \mathrm{ml}$ of $0.01 \mathrm{M}$ potassium phosphate buffer, $\mathrm{pH} 7.6$ (hereafter called phosphate buffer), and disrupted by three cycles of freezing and thawing. Whole cells and nuclei were removed by centrifugation for $10 \mathrm{~min}$ at $2,000 \mathrm{rpm}$. The supernate from this centrifugation constituted the lysate.

For certain experiments, the lysate proteins were separated from endogenous low molecular weight compounds by gel filtration. The lysate was passed through a $20-\mathrm{ml}$ column of Sephadex G-25 coarse which had been equilibrated with phosphate buffer, eluting with the same buffer and collecting $1.1-\mathrm{ml}$ fractions. The two most turbid fractions were pooled. These pooled fractions constituted the gel-filtered lysate.

In all cases, centrifugation was performed on an IEC model PR-J refrigerated centrifuge equipped with a Model 269 head (Damon Engineering Inc., Needham Heights, Mass.). All the above procedures were carried out at $0-4^{\circ} \mathrm{C}$. Once prepared, the lysate was stored at room temperature.

Protein in the lysate was determined by the Lowry method (17) using bovine serum albumin as standard. Lysis of $10^{7}$ cells yielded $0.29 \pm 0.09 \mathrm{SD} \mathrm{mg}$ protein.

$\mathrm{O}_{3}^{-}$production by intact cells. $\mathrm{O}_{2}^{-}$production by intact cells was determined by the method of Curnutte and Babior (9).

$\mathrm{O}_{s^{-}}^{-}$production by lysates. $\mathrm{O}_{2}^{-}$production by lysates was determined by measuring superoxide dismutase-sensitive NBT reduction, using each reaction mixture as its own control. NBT solution was prepared by dissolving $100 \mathrm{mg}$ of NBT in $100 \mathrm{ml} \mathrm{HBSS}$ to which $2 \mathrm{ml} 0.5 \mathrm{M}$ potassium phosphate buffer $(\mathrm{pH}$ 7.4) had been added. The solution was filtered through Whatman 1 paper before use. Two $1-\mathrm{ml}$ cuvettes with identical path lengths $(1.000 \mathrm{~cm})$ were rinsed with distilled water followed by absolute ethanol and carefully dried under a stream of nitrogen. Into one cuvette was placed $10 \mu \mathrm{l}$ of superoxide dismutase $[0.6 \mathrm{mg} /$ $\mathrm{ml}$ in $0.03 \mathrm{mM}$ potassium phosphate buffer $(\mathrm{pH} 7.8)]$; the other received an equal volume of water. Reaction mixtures were prepared containing NBT solution $(2.0 \mathrm{ml})$, lysate, and reduced pyridine nucleotide dissolved in phosphate buffer, together with sufficient additional phosphate buffer to bring the total volume to $2.5 \mathrm{ml}$. Exactly 1.00 $\mathrm{ml}$ of reaction mixture was pipetted into each of the cuvettes. After mixing the contents, the cuvettes were placed into a Cary Model $118 \mathrm{C}$ recording spectrophotometer with the dismutase-containing cuvette in the reference position (Cary Instruments, Fairfield, N. J.). The incubation was conducted at ambient temperature $\left(24-25^{\circ} \mathrm{C}\right)$. The difference in rates of NBT reduction in the cuvettes was ordinarily followed for $10 \mathrm{~min}$ at $530 \mathrm{~nm}$. Spectral noise present at the beginning of the incubation had subsided by $5 \mathrm{~min}$; reaction rates were found to be constant for the next 30 min. Rates were calculated from the change in absorbance between 5 and $10 \mathrm{~min}$ using a $\Delta \epsilon_{\mathrm{mM}}$ (reduced minus oxi- dized) for NBT of $18.3^{2}$ and a stoichiometric relationship between $\mathrm{O}_{2}^{-}$formation and NBT reduction of two to one. The stoichiometry of the reaction between $\mathrm{O}_{2}^{-}$and NBT was established by comparing the dismutase-inhibitable reduction of NBT with that of cytochrome $c$ in a system containing xanthine oxidase plus purine as a source of $\mathrm{O}_{2}^{-}$. Reaction mixtures contained $1 \mu \mathrm{mol}$ purine, $0.02 \mathrm{U}$ xanthine oxidase, $10 \mu \mathrm{mol}$ potassium phosphate buffer $(\mathrm{pH} 7.4)$, and NBT or cytochrome $c$ in quantities that were shown in preliminary experiments to be sufficient to trap all the $\mathrm{O}_{2}^{-}$ generated $(0.2 \mu \mathrm{mol}$ and $0.05 \mu \mathrm{mol}$, respectively $)$ in a total volume of $1 \mathrm{ml}$. The reactions, which were carried out at ambient temperature, were begun with xanthine oxidase and followed for $2 \mathrm{~min}$ in the recording spectrophotometer, measuring absorbance at $530 \mathrm{~nm}$ or $550 \mathrm{~nm}$ for reaction mixtures containing NBT or cytochrome $c$, respectively. Superoxide dismutase $(2 \mu \mathrm{l}$ of a solution containing enzyme at a concentration of $3 \mathrm{mg} / \mathrm{ml}$ ) was then added, and absorbance was followed for another $2 \mathrm{~min}$. The dismutaseinhibitable reaction rates were determined from the differences between the two rates. Further additions of dismutase caused no further change in the rates. These experiments showed that for comparable rates of $\mathrm{O}_{2}^{-}$production a $1 \mathrm{U}$ absorbance change at $550 \mathrm{~nm}$ in the cytochrome $c$-containing reaction mixtures corresponded to an $0.55 \mathrm{U}$ change at $530 \mathrm{~nm}$ in the NBT-containing mixtures. From this figure and the reported $\Delta \epsilon_{\mathrm{mM}}$ (reduced minus oxidized) for cytochrome $c$ at $550 \mathrm{~nm}$ of 15.5 , it can be calculated that the $\epsilon_{\mathrm{m}} \mathrm{a}$ at $530 \mathrm{~nm}$ for the reduction of NBT by two equivalents of $\mathrm{O}_{2}^{-}$is 17.1 , a value in good agreement with the figure obtained by dithionite reduction. Each NBT molecule reduced thus represents two molecules of $\mathrm{O}_{2}^{-}$formed.

We also performed experiments to exclude the possibility that $\mathrm{O}_{2}^{-}$-dependent $\mathrm{NBT}$ reduction was being artifactually amplified by a free radical chain process involving reduced pyridine nucleotides. An example of a sequence of reactions that would lead to such a situation is the following:

$$
\mathrm{O}_{2}+\mathrm{e}^{-} \rightarrow \mathrm{O}_{2}^{-}
$$

Initiation

$$
\begin{aligned}
& \left.\begin{array}{c}
\mathrm{O}_{2}^{-}+\mathrm{NBT} \rightarrow \mathrm{O}_{2}+\mathrm{NBT} \cdot \\
\mathrm{NBT} \cdot+\mathrm{NADPH} \rightarrow \text { formazan }+\mathrm{NADP} \cdot
\end{array}\right\} \text { Propagation } \\
& \mathrm{NADP} .+\mathrm{O}_{2} \rightarrow \mathrm{NADP}+\mathrm{O}_{2}
\end{aligned}
$$

This possibility was examined by comparing dismutaseinhibitable NBT reduction in the presence and absence of NADPH. Contrary to the stimulation in NBT reduction predicted by the above mechanism, the addition of $0.1 \mathrm{mM}$ NADPH to the NBT-containing reaction mixture described in the preceding paragraph diminished NBT reduction to $75 \%$ of control. Amplification by a free radical chain process therefore seems unlikely.

The results obtained with lysates are reported in terms of nanomoles $\mathrm{O}_{2}^{-}$produced. This method of reporting was chosen to facilitate comparison between the present results and previously reported data. We recognize that it is not strictly correct, since what is actually being measured is $\mathrm{O}^{-}$-dependent NBT reduction, and it is likely that some portion of the $\mathrm{O}_{2}^{-}$generated in the reaction mixture is not being detected.

Total NBT reduction was determined from the difference in $A_{\text {xiso }}$ at 0 and $10 \mathrm{~min}$ of the sample (i.e., dismutase free) cuvette, read against air.

\footnotetext{
${ }^{2} \Delta \epsilon_{\mathrm{mM}}$ was measured by determining the difference in absorbance at $530 \mathrm{~nm}$ of unreacted and dithionite-reduced solutions of NBT ( $35 \mu \mathrm{M}$, in phosphate buffer).
} 
Activated serum. Activated serum was prepared the day of the experiment. Serum was diluted $3: 7(\mathrm{vol} / \mathrm{vol})$ with HBSS. $1.5 \mathrm{ml}$ of the diluted serum was activated by incubation with $0.75 \mathrm{ml}$ of a suspension of $E$. coli $0111: \mathrm{B} 4$ in HBSS $\left(A_{\text {220 }}\right.$ of the bacterial suspension $\left.=0.45\right)$ at $37^{\circ} \mathrm{C}$ for $30 \mathrm{~min}$. After activation, the bacteria were removed by centrifugation at $2,000 \mathrm{rpm}$ for $15 \mathrm{~min}$ at $4^{\circ} \mathrm{C}$. The activated serum was stored in ice until used.

Paticnts. Studies were performed on granulocytes from two male patients with X-linked CGD. One patient (case 1 , reference 11 ) has been reported previously. The diagnosis in the other patient (age 3) was based on a typical clinical history, failure of his granulocytes to reduce NBT, normal glucose-6-phosphate dehydrogenase levels, and the presence of a similar condition in each of his two male siblings. His mother and maternal grandmother were shown to be carriers by quantitative NBT testing.

\section{RESULTS}

When reaction mixtures containing lysate and NADPH were incubated under the conditions described above, a substantial difference in the rate of NBT reduction between the two cuvettes was observed, indicating that $\mathrm{O}_{3}{ }^{-}$-mediated NBT reduction was occurring (Table I). This difference disappeared when active dismutase was replaced by dismutase inactivated by autoclaving for 20 min at $121^{\circ} \mathrm{C}$, confirming the $\mathrm{O}_{2}^{-}$-dependence of the process. Little difference in NBT reduction was seen when the homogenate was replaced with albumin or was heated before use, or when NADPH was omitted from the reaction mixture. A difference was observed, however, when NADPH was replaced with $\mathrm{NADH}$, indicating that the latter also served as a reducing agent

TABLE I

$\mathrm{O}_{2}^{-}$Production by Cell-Free Lysates of Human Granulocytes Using Reduced Pyridine Nucleotides as the Source of Electrons

\begin{tabular}{llr}
\hline \multicolumn{1}{c}{ Conditions } & $\begin{array}{l}\text { Dismutase in } \\
\text { reference cell }\end{array}$ & $\mathrm{O}^{-}$- detected \\
Complete reaction mixture & & $\begin{array}{r}n m o l / m l / h \\
18.4 \pm 4.6\end{array}$ \\
Boiled lysate $\neq$ & Active & $-0.6 \pm 0.6$ \\
Lysate replaced with albumin & Active & $2.2 \pm 1.0$ \\
NADPH omitted & Active & $0.4 \pm 1.0$ \\
NADH instead of NADPH & Active & $2.2 \pm 0.6$ \\
\hline
\end{tabular}

* 15 min at $121^{\circ} \mathrm{C}$.

$\ddagger$ Heated $1 \mathrm{~min}$ in boiling water.

Incubations were conducted as described in the Methods section with modifications as noted. Concentrations were: lysate protein, $0.12 \mathrm{mg} / \mathrm{ml}$; reduced pyridine nucleotide $0.2 \mathrm{mM}$. Results are expressed as mean $\pm \mathrm{SE}$ for three experiments. Cells from a different subject were used for each of the experiments.

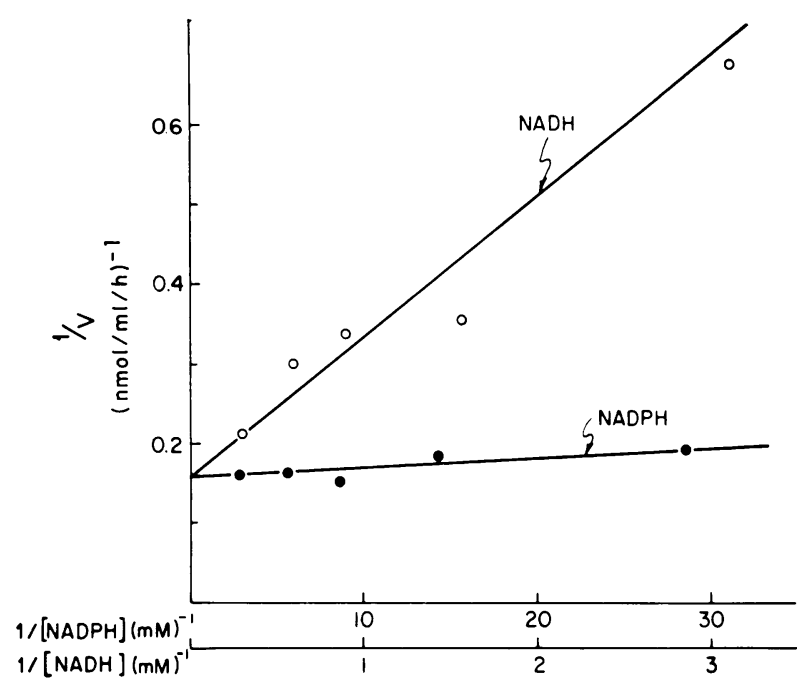

Figure 1 Reciprocal plots of the rate of $\mathrm{O}_{2}^{-}$production as a function of NADPH or NADH concentration. Incubations were conducted as described in the Methods section using lysates which had been subjected to gel filtration. Concentrations were: lysate protein, $0.08 \mathrm{mg} / \mathrm{ml}$; reduced pyridine nucleotide, as indicated.

for the production of $\mathrm{O}_{2}^{-}$by granulocyte lysates. Comparison of dismutase-inhibitable NBT reduction with total NBT reduction by these preparations revealed that the $\mathrm{O}_{2}{ }^{-}$-dependent process accounted for $53 \pm 6 \mathrm{SE} \%$ of the formazan produced in these reaction mixtures. This proportion was not altered when the dismutase concentration in the reference cuvet was increased fivefold.

Although either pyridine nucleotide could serve as reducing agent, measurements of rates of $\mathrm{O}_{2}^{-}$production as a function of nucleotide concentration showed that NADPH was the preferred reductant in this system. Lineweaver-Burk plots of the data from these experiments are shown in Fig. 1. The data used to prepare these plots were also fitted to the Michaelis-Menten equation by a nonlinear least-square procedure. The $K_{m}$ for NADPH obtained by the least-squares fit is $8.6 \pm 4.6 \mu \mathrm{M}$, while the $K_{m}$ for $\mathrm{NADH}$ is $0.83 \pm 0.30$ $\mathrm{mM}$. The affinity of the $\mathrm{O}_{2}^{-}$-forming system for $\mathrm{NADPH}$ is thus two orders of magnitude greater than its affinity for NADH.

Alternatively, these findings may be interpreted in terms of two $\mathrm{O}_{3}^{-}$-generating systems, one specific for $\mathrm{NADPH}$ and the other specific for NADH. Two lines of evidence, however, suggest that only one system is present. First, the maximum velocities $\left(\tau^{\prime} m\right)$ for the two nucleotides were statistically identical $(P>0.4$ with $8 \mathrm{dF}$, by Student's $t$ test). Secondly, rates of $\mathrm{O}^{-}$ production in reaction mixtures in which portions of the NADPH were replaced by $\mathrm{NADH}$ (in fivefold molar excess over the amount of NADPH removed) 


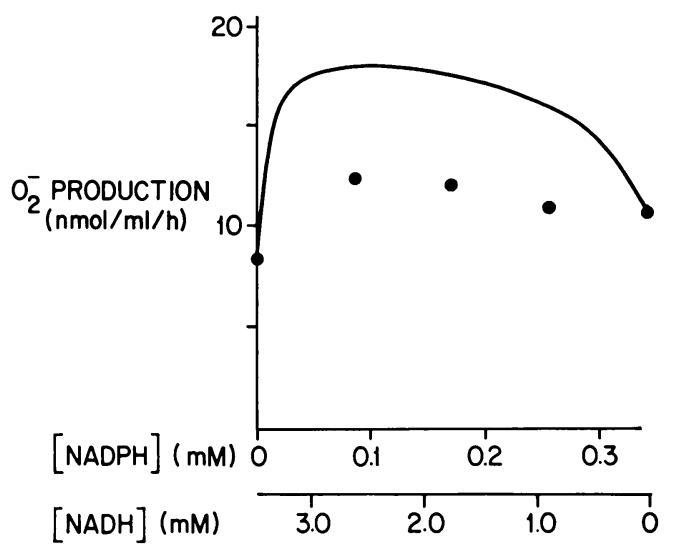

Figure $2 \mathrm{O}_{2}^{-}$production with mixtures of NADPH and $\mathrm{NADH}$ as electron donor. Incubations were conducted as described in the Methods section. Concentrations were: lysate protein, $0.12 \mathrm{mg} / \mathrm{ml}$; reduced pyridine nucleotide, as indicated. The points represent the experimental results. The continuous line represents the variation in reaction rate as the reduced pyridine nucleotide concentrations are varied over the range used in this experiment, calculated according to a model involving two different $\mathrm{O}_{2}{ }^{-}$-generating systems, one specific for NADH and the other for NADPH. The calculation was performed using $K_{m}$ 's of $8.6 \mu \mathrm{M}$ and $0.83 \mathrm{mM}$ for $\mathrm{NADPH}$ and $\mathrm{NADH}$, respectively, and the reaction rates measured at $0.34 \mathrm{mM}$ NADPH, $0 \mathrm{mM}$ $\mathrm{NADH}$ (the extreme left hand point in the figure) and $0 \mathrm{mM}$ NADPH, $3.4 \mathrm{mM} \mathrm{NADH}$ (the extreme right hand point). Each individual nucleotide was assumed to obey conventional saturation kinetics. The Michaelis-Menten equation was used to determine the reaction rates for the separate nucleotides at corresponding nucleotide concentrations (corresponding concentrations were those which could be connected by a vertical line drawn between the two scales on the $\mathrm{X}$-axis of the figure). The values for the individual nucleotides were added to obtain the rates plotted as the continuous line.

were considerably smaller than the rates predicted if two independent $\mathrm{O}_{2}^{-}$-generating systems were present (Fig. 2).

Experiments with other reducing agents showed that pyridine nucleotides were specifically required as reductants in the $\mathrm{O}_{3}^{-}$-forming reaction. Table II shows $\mathrm{O}_{a}^{-}$production by granulocyte lysates in the presence of a number of potential reducing agents normally present in the cell, including glycolytic and hexosemonophosphate shunt intermediates, glutathione, and ascorbic acid. ${ }^{3}$ Of the agents tested, the only ones with which significant $\mathrm{O}_{2}^{-}$production took place were the two pyridine nucleotides.

$\mathrm{O}_{3}^{-}$production by intact granulocytes is unaffected by $1 \mathrm{mM}$ cyanide (18). To determine whether $\mathrm{O}_{2}^{-}$pro-

${ }^{3}$ With ascorbic acid, a brief burst of $\mathrm{O}_{2}{ }^{-}$-dependent $\mathrm{NBT}$ reduction was observed which subsided after 5 min. Inasmuch as this burst occurred with boiled as well as active lysate, it is not regarded as significant. duction by granulocyte lysates is similarly insensitive to cyanide, $\mathrm{O}_{2}^{-}$-dependent $\mathrm{NBT}$ reduction by three lysates was measured in the absence and presence of 1 $\mathrm{mM} \mathrm{KCN}$. In these experiments, the protein concentration was $0.12 \mathrm{mg} / \mathrm{ml}$, and the concentration of $\mathrm{NADPH}$ was $40 \mu \mathrm{M}$. Rates of $\mathrm{O}_{2}^{-}$production in the presence of $\mathrm{KCN}$ were $20.4 \pm 7.2 \mathrm{SE} \mathrm{nmol} / \mathrm{ml}$ per $\mathrm{h}$ compared with control values of $18.0 \pm 5.2 \mathrm{nmol} / \mathrm{ml}$ per $h$. These results indicate that, as with intact cells, $\mathrm{O}_{3}^{-}$production by granulocyte lysates is not affected by cyanide.

The dependence of $\mathrm{O}_{2}^{-}$production on protein concentration is shown in Fig. 3. The disproportionate rise in the rate of $\mathrm{O}_{2}^{-}$production with increasing protein concentration was consistently observed with lysates from cells that had been kept in ice for the entire period between preparation and lysis. Different results were obtained, however, with cells that had been incubated for $30 \mathrm{~min}$ at $37^{\circ} \mathrm{C}$ before lysis (see below, Fig. 6). Further study will be necessary before this observation can be explained.

It is of interest to compare the rate of $\mathrm{O}_{2}^{-}$production by granulocyte lysates with the rate seen in intact cells. Measurements reported to date of $\mathrm{O}_{2}{ }^{-}$production by intact cells have been made at $37^{\circ} \mathrm{C}$, whereas for technical reasons experiments with lysates have been carried out at $25^{\circ} \mathrm{C}$. To provide a basis for comparison, $\mathrm{O}_{2}^{-}$production by a preparation of intact cells was measured at 37 and $25^{\circ} \mathrm{C}$ (Fig. 4). The maximum rate

TABLE II

Specificity of Reduced Pyridine Nucleotides as Electron Donors for $\mathrm{O}_{2}^{-}$

\begin{tabular}{lc}
\hline \multicolumn{1}{c}{ Reducing agent } & $\mathrm{O}_{2}{ }^{-}$production \\
\hline Experiment 1 & $n m o l / m l / h$ \\
NADPH & 24.0 \\
Glucose-6-phosphate & 2.2 \\
6-Phosphogluconic acid & 3.0 \\
Glutathione & 2.4 \\
Sodium lactate & 0.4 \\
Glyceraldehyde-3-phosphate & 0 \\
None & 2.6 \\
Experiment 2 & \\
NADPH & 12.4 \\
Ascorbic acid* & 4.4 \\
Ascorbic acid, boiled lysateł & 3.2
\end{tabular}

* Added as a $1 \mathrm{mM}$ solution prepared shortly before starting the incubation.

$\ddagger$ Heated $1 \mathrm{~min}$ in boiling water.

Incubations were conducted as described in the Methods section using as a source of electrons the reducing agent indicated. Concentrations were: protein, $0.12 \mathrm{mg} / \mathrm{ml}$; reducing agent, $40 \mu \mathrm{M}$.

1038 B. M. Babior, J. T. Curnutte, and R. S. Kipnes 


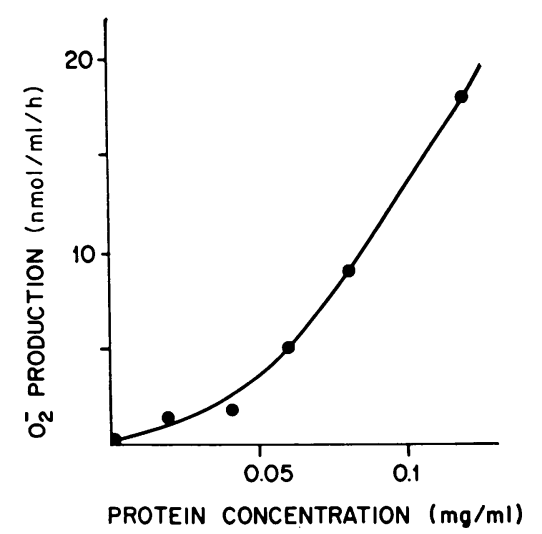

FIGURE $3 \mathrm{O}_{2}^{-}$production as a function of the concentration of protein in the reaction mixture. Incubations were conducted as described in the Methods section. Concentrations were: NADPH, $0.2 \mathrm{mM}$; protein, as indicated.

at $37^{\circ} \mathrm{C}, 60.6 \mathrm{nmol} / \mathrm{h} / 3 \times 10^{\circ}$ cells, was comparable to previously reported rates $(9-11)$. At $25^{\circ} \mathrm{C}$, the rate was considerably lower, maximum $\mathrm{O}_{2}^{-}$production falling

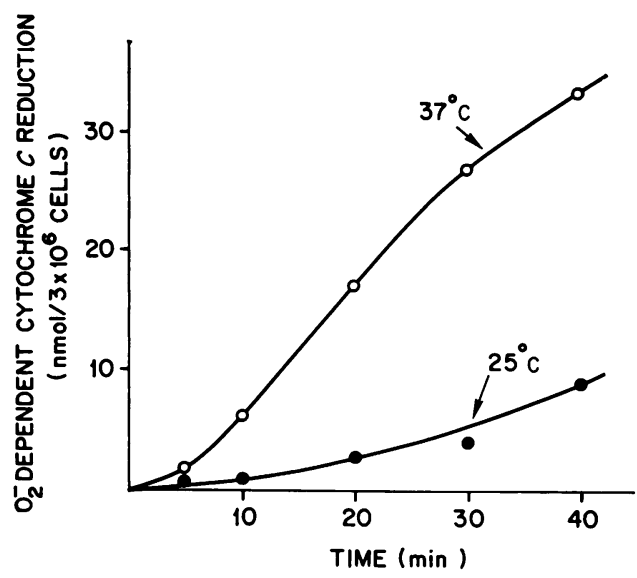

Figure $4 \mathrm{O}_{2}^{-}$-dependent cytochrome $c$ reduction by intact granulocytes incubated at 25 and $37^{\circ} \mathrm{C}$. Granulocytes (1.8 $\times 10^{7}$ cells) in $3.0 \mathrm{ml}$ HBSS were placed in each of four $10-\mathrm{ml}$ Vacutainer ${ }^{\circledR}$ tubes. Superoxide dismutase $[20 \mu 1$ of a solution containing $3 \mathrm{mg} / \mathrm{ml}$ in $0.15 \mathrm{mM}$ potassium phosphate buffer $(\mathrm{pH} 7.8)$ ] was added to two of the tubes, and an equal volume of water was added to the other tubes. The reaction mixtures were then placed in a $37^{\circ} \mathrm{C}$ water bath. $2 \mathrm{~min}$ later, $2.0 \mathrm{ml}$ of serum [autologous serum diluted $3: 7(\mathrm{vol} / \mathrm{vol})$ with HBSS] and $1.0 \mathrm{ml}$ of bacterial suspension $\left(3 \times 10^{9} E\right.$. coli $\left.\mathrm{C} / \mathrm{ml} \mathrm{HBSS}\right)$ were added to each tube. The incubations were continued for 8 more min. Then $0.32 \mathrm{ml}$ cytochrome $c(1.5 \mathrm{mM}$ in water) was added to each tube. Immediately, $0.75 \mathrm{ml}$ of reaction mixture was withdrawn from each tube and placed on ice, after which two of the tubes (one with dismutase and one without) were placed in a $25^{\circ} \mathrm{C}$ water bath. Samples $(0.75$ $\mathrm{ml}$ ) were withdrawn from each tube at the times noted and placed on ice. $\mathrm{O}_{2}^{-}$-dependent cytochrome $c$ reduction at each time point in the incubations performed at each of the two temperatures was then determined as previously described (9).

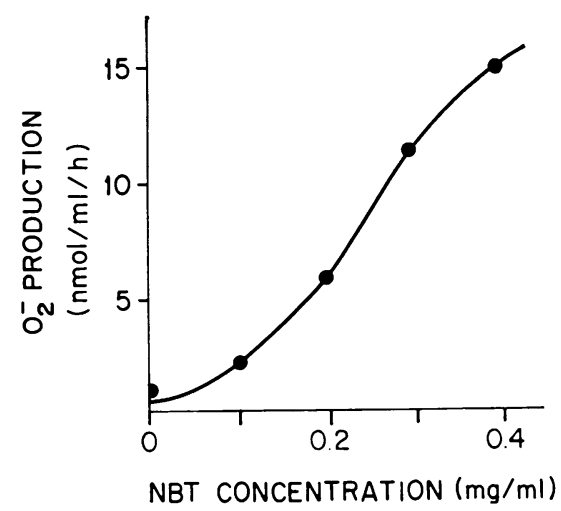

Figure $5 \mathrm{O}_{2}^{-}$production as a function of NBT concentration. Incubations were conducted as described in the Methods section, except that the NBT concentration was varied as shown. Concentrations of other constituents were: protein, $0.12 \mathrm{mg} / \mathrm{ml}$; NADPH, $40 \mu \mathrm{M}$.

to $19.1 \mathrm{nmol} / \mathrm{h} / 3 \times 10^{6}$ cells. In the experiments with granulocyte lysates, presented in Table I, the concentration of protein in the reaction mixtures corresponds to $4.1 \times 10^{6}$ intact cells $/ \mathrm{ml}$. Comparison of Table I with Fig. 4 shows that the rates of $\mathrm{O}_{2}^{-}$production by granulocyte lysates (using $\mathrm{NADPH}$ as reducing agent) are comparable to the rate of $\mathrm{O}_{2}^{-}$production by the corresponding number of intact granulocytes incubated at a similar temperature. Moreover, the observed rates merely place a lower limit on true rates of $\mathrm{O}_{2}^{-}$production by lysates, since the increase in $\mathrm{O}_{2}^{-}$-dependent $\mathrm{NBT}$ reduction with increasing NBT concentration seen even at the highest concentration of NBT tested (Fig. 5) indicates that a substantial amount of $\mathrm{O}_{2}^{-}$is going undetected in these experiments (cf. Fig. 3 in reference 9 ). It is apparent that $\mathrm{O}_{2}^{-}$production by granulocyte lysates under the present experimental conditions is quantitatively significant with respect to rates of $\mathrm{O}_{2}^{-}$ production by intact cells.

One of the characteristic features of $\mathrm{O}_{2}^{-}$production by granulocytes is its stimulation in the presence of serum plus bacteria or serum that had been previously activated by exposure to bacteria (9). To ascertain whether $\mathrm{O}_{2}^{-}$production by granulocyte lysates displays similar changes, experiments were conducted comparing $\mathrm{O}_{3}^{-}$-dependent $\mathrm{NBT}$ reduction by lysates from cells exposed to activated serum with that by lysates from the same population of cells not so exposed. Table III shows $\mathrm{O}_{2}^{-}$production at two concentrations of NADPH by lysates from cells which had been incubated for 30 min in activated serum and from cells which had been incubated for a similar time in HBSS, while Fig. 6 shows the protein concentration dependence of $\mathrm{O}_{2}^{-}$production by lysates from serum- and HBSS-treated cells. Rates of $\mathrm{O}_{2}^{-}$production by lysates from the two classes of cells were similar under all the experimental condi- 
TABLE III

$\mathrm{O}_{2}-$ Production by Lysates Prepared from Serum- and HBSS-Treated Granulocytes

\begin{tabular}{ccc}
\hline \multirow{2}{*}{$\begin{array}{c}\text { NADPH } \\
\text { concentration }\end{array}$} & \multicolumn{2}{c}{$\mathrm{O}^{-}$production } \\
\cline { 2 - 3 } & Serum treated & HBSS treated \\
\hline$\mu . M$ & \multicolumn{2}{c}{$n \mathrm{nmol} / \mathrm{ml} / \mathrm{h}$} \\
40 & $10.2 \pm 0.8$ & $9.6 \pm 1.2$ \\
4 & $6.0 \pm 1.0$ & $6.2 \pm 0.6$ \\
\hline
\end{tabular}

Granulocytes were prepared as usual and suspended in $4 \mathrm{ml}$ HBSS. $2 \mathrm{ml}$ of this suspension were incubated for $15 \mathrm{~min}$ at $37^{\circ} \mathrm{C}$ in a $10-\mathrm{ml}$ Vacutainer tube with $2 \mathrm{ml} \mathrm{HBSS}$; the remainder was incubated under the same conditions with $2 \mathrm{ml}$ activated serum (see Methods). The reaction vessels were then chilled in ice and then centrifuged at $1,000 \mathrm{rpm}$ for $4 \mathrm{~min}$ at $4^{\circ} \mathrm{C}$. The supernates were discarded, and the pellets of cells washed once with ice cold HBSS. Each portion of cells was suspended in $1.5 \mathrm{ml}$ phosphate buffer, and lysates were prepared as described in the Methods section. Lysates were incubated for $30 \mathrm{~min}$ at room temperature and then subjected to gel filtration. $\mathrm{O}_{2}^{-}$production was then determined as usual. Concentrations were: protein, $0.12 \mathrm{mg} / \mathrm{ml}$; NADPH, as indicated. Results are expressed as mean $\pm \mathrm{SE}$ for three experiments. Cells from a different subject were used for each of the experiments.

tions and resembled rates obtained with lysates from unincubated cells (cf. Table I, Fig. 1 and 3 ). It thus appears that stimulation of cells before lysis by incubation with activated serum has little effect on the $\mathrm{O}_{2}{ }^{-}-$ generating activity of the lysates.

CGD is a condition (or group of conditions) in which the respiratory burst that normally follows exposure of the granulocyte to ingestible particles fails to occur $(1,11,19)$. To determine whether $\mathrm{O}_{2}^{-}$production by this cell-free system is altered in this condition, lysates from the granulocytes of two patients with CGD, one of whose cells have previously been shown to produce no $\mathrm{O}_{2}^{-}$(case 1 , reference 11 ), were prepared

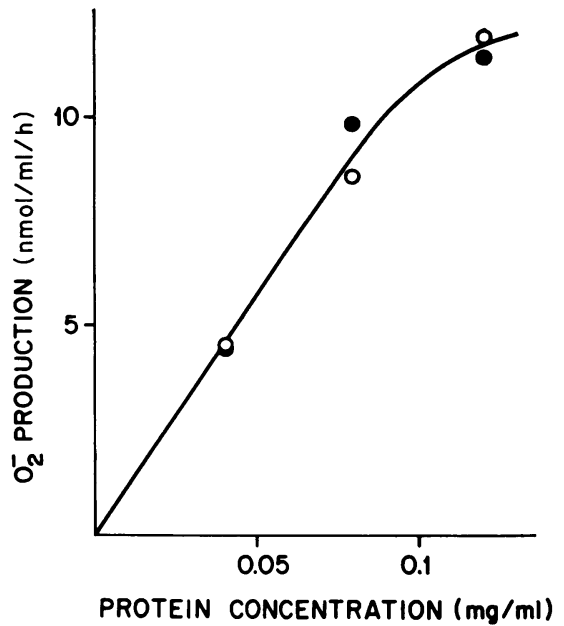

FIGLRE 6 Protein concentration dependence of $\mathrm{O}_{2}^{-}$production by lysates prepared from serum- and HBSS-treated granulocytes. Lysates from serum- and HBSS-treated granulocytes were prepared as described in Table III. Incubations were conducted as described in the Methods section. Concentrations were: NADPH, $40 \mu \mathrm{M}$; protein, as indicated. $\bullet$, serum treated; $O$, HBSS treated.

and tested as described in Table IV. Despite the defect present in intact cells, $\mathrm{O}_{2}^{-}$production by the CGD cell lysates at two concentrations of reduced pyridine nucleotide was, if anything, greater than control.

\section{DISCUSSION}

In designing a spectrophotometric assay to quantitate $\mathrm{O}_{2}^{-}$production by granulocyte homogenates, the problem of high blanks resulting from $\mathrm{O}_{2}^{-}$-independent changes in the absorbance of the reaction mixtures had to be overcome. This difficulty was dealt with by designing an assay in which portions of a single reaction mixture were incubated in the presence and absence of superoxide dismutase under conditions other-

TABLE IV

$\mathrm{O}_{2}-$ Production by Lysates Prepared from CGD Granulocytes

\begin{tabular}{|c|c|c|c|c|c|}
\hline \multirow[b]{3}{*}{ Pyridine nucleotide } & \multicolumn{5}{|c|}{$\mathrm{O}_{2}^{-}$production } \\
\hline & \multicolumn{3}{|c|}{ Patient 1} & \multicolumn{2}{|c|}{ Patient 2} \\
\hline & Patient & Control & Mixed & Patient & Control \\
\hline & \multicolumn{5}{|c|}{$n \mathrm{~mol} / \mathrm{ml} / \mathrm{h}$} \\
\hline $\mathrm{NADPH}, 0.2 \mathrm{mM}$ & 29.0 & 27.8 & 27.8 & 29.6 & 17.3 \\
\hline NADPH, $0.02 \mathrm{mM}$ & 23.8 & 23.8 & - & 21.6 & 15.1 \\
\hline $\mathrm{NADH}, 0.2 \mathrm{mM}$ & 15.8 & 19.8 & 21.2 & 7.7 & 6.5 \\
\hline
\end{tabular}

Incubations were conducted as described in Methods. Concentrations were: protein, $0.12 \mathrm{mg} / \mathrm{ml}$; reduced pyridine nucleotide, as noted. "Mixed" refers to reaction mixtures containing equal amounts of CGD and control lysate protein (total protein concentration $0.12 \mathrm{mg} / \mathrm{ml}$ ). 
wise as close to identical as possible. Under these assay conditions the high blanks were no longer a problem because of cancellation between the sample and reference incubations of changes in absorbance due to $\mathrm{O}_{2}{ }^{-}$-independent processes.

The pyridine nucleotide requirement for $\mathrm{O}_{2}^{-}$production is in accord with a lot of other evidence pointing to the involvement of this class of cofactor in the phagocytosis-induced oxygen-consuming reactions of the granulocyte $(1,20,21)$. While it is widely agreed that a pyridine nucleotide is the source of electrons for these reactions, there is disagreement as to whether the primary reductant is $\mathrm{NADH}$ or NADPH (1, 20-23). The present results support the notion that, in human cells at least, the primary reductant is NADPH. From studies reported by this (9) and other (10) laboratories, it seems reasonable to postulate that $\mathrm{O}_{2}^{-}$is the product of the first reaction of the sequence responsible for the respiratory burst. The present results suggest that this reaction is catalyzed by a single enzyme (or enzyme system) which, while it displays dual specificity, shows a marked preference for NADPH over NADH, according to measurements of $K_{m}$.

There have been many studies with various brokencell preparations aimed at understanding the biochemical defect in X-linked CGD. Most of these studies have been predicated on the hypothesis that the lesion in CGD involves one of the oxygen-metabolizing enzymes responsible for the respiratory burst. Data obtained so far, however, have provided only equivocal support for this hypothesis. The proposal that the lesion in CGD is a defect in the soluble granulocyte $\mathrm{NADH}$ oxidase has been supported by studies from one laboratory (24) but not by studies from two other laboratories $(19,25)$. Very recently a defect in the particulate $\mathrm{NADPH}$ oxidase of CGD granulocytes has been reported (25). In view of the rather inconclusive nature of the evidence concerning defects in oxygen-metabolizing enzymes, it has been suggested that the metabolic lesion in CGD may involve an enzyme system physiologically connected to, but not identical with, the oxygen-consuming enzymes directly responsible for the respiratory burst (1). This possibility finds some support in studies showing differences in degranuation between normal and CGD cells $(26,27)$.

The previous results most closely related to our own observations are those reported by Nathan et al. in 1969. In attempting to reproduce in a cell-free system one of the characteristic functional defects of CGD granulocytes, namely the failure of these cells to reduce NBT, these workers found instead active NBT reduction (not necessarily $\mathrm{O}_{2}^{-}$-mediated) by a cell-free preparation from CGD granulocytes that were unable to reduce NBT before their disruption (26). We report here similar observations, namely, that $\mathrm{O}_{2}^{-}$production by lysates prepared from CGD cells was the same as its production by lysates from normal cells, notwithstanding our previous demonstration of a profound defect in $\mathrm{O}_{2}^{-}$ production by intact CGD granulocytes (10). On the other hand, we recently studied pyridine nucleotidedependent $\mathrm{O}_{2}^{-}$production in a cell-free system prepared by another method and found in these experiments that preparations from CGD granulocytes failed to generate $\mathrm{O}_{2}^{-}(28)$, a finding that appears superficially to be in direct conflict with the observations reported in this paper. This conflict may be reconciled under the hypothesis that the CGD lesion lies outside the oxygen-metabolizing system, or alternatively, that the granulocyte contains two separate $\mathrm{O}_{2}^{-}$-forming enzymes, one of which is inactive in CGD. Which if either of the above represents the true defect in $\mathrm{X}$-linked CGD remains to be determined.

\section{ACKNOWLEDGMENTS}

We are grateful to Dr. Dana Whitten of the Boston Floating Hospital and Dr. Richard Greco of the Rhode Island Hospital, Providence, R. I. for permission to obtain samples of blood from patients under their care with chronic granulomatous disease.

This work was supported in part by Public Health Service Grants AI-11827, AM-16589, and RR-05598 and by Contract DAMD17-74-C-4055 from the U. S. Army Medical Research and Development Command.

\section{REFERENCES}

1. Karnovsky, M. L. 1973. Chronic granulomatous disease-pieces of a cellular and molecular puzzle. Fed. Proc. 32: 1527-1533.

2. Sbarra, A. J., and M. L. Karnovsky. 1959. The biochemical basis of phagocytosis. I. Metabolic changes during the ingestion of particles by polymorphonuclear leukocytes. J. Biol. Chem. 234: 1355-1362.

3. Iyer, G. Y. N., M. F. Islam, and J. H. Quastel. 1961. Biochemical aspects of phagocytosis. Nature (Lond.). 192: $535-541$.

4. Paul, B., and A. J. Sbarra. 1968. The role of the phagocyte in host-parasite interactions. XIII. The direct quantitative estimation of $\mathrm{H}_{2} \mathrm{O}_{2}$ in phagocytizing cells. Biochim. Biophy's. Acta. 156: 168-178.

5. Baehner, R. L., N. Gilman, and M. L. Karnovsky. 1970. Respiration and glucose oxidation in human and guinea pig leukocytes: comparative studies. J. Clin. Invest. 49: 692-700.

6. Klebanoff, S. J. 1967. A peroxidase-mediated antimicrobial system in leukocytes. J. Clin. Invest. 46: 1078. (Abstr.)

7. Klebanoff, S. J., and C. B. Hamon. 1972. Role of myeloperoxidase-mediated antimicrobial systems in intact leukocytes. J. Reticuloendothel. Soc. 12: 170-196.

8. Babior, B. M., R. S. Kipnes, and J. T. Curnutte. 1973. Biological defense mechanisms. The production by leukocytes of superoxide, a potential bactericidal agent. $J$. Clin. Invest. 52: 741-744.

9. Curnutte, J. T., and B. M. Babior. 1974. Biological defense mechanisms. The effect of bacteria and serum 
on superoxide production by granulocytes. J. Clin. Inz'est. 53: 1662-1672.

10. Weening, R. S., R. Wever, and D. Roos. 1975. Quantitative aspects of the producion of superoxide radicals by phagocytizing human granulocytes. J. Lab. Clin. Med. 85: 245-252.

11. Curnutte, J. T., D. M. Whitten, and B. M. Babior. 1974. Defective superoxide production by granulocytes from patients with chronic granulomatous disease. $N$. Engl. J. Med. 290: 593-597.

12. Klebanoff, S. J. 1974. Role of the superoxide anion in the myeloperoxidase-mediated antimicrobial system. J. Biol. Chem. 249: 3724-3728.

13. Gregory, E. M., and I. Fridovich. 1974. Oxygen metabolism in Lactobacillus plantarum. J. Bacteriol. 117: 166-169.

14. Babior, B. M., J. T. Curnutte, and R. S. Kipnes. 1975 Biological defense mechanisms. Evidence for participation of superoxide in bacterial killing by xanthine oxidase. J. Lab. Clin. Med. 85: 235-244.

12. Jondol, M., H. Wigzell, and F. Auiti. 1973. Human L. S. Webb, J. Lehmeyer, and K. V. Rajagopalan. 1975. Superoxide anion generation and phagocytic bactericidal activity. In The Phagocytic Cell and Host Resistance. J. A. Bellanti and D. H. Dayton, editors. Raven Press, New York.

16. Allen, R. C., S. J. Yevich, R. W. Orth, and R. H. Steele. 1974. The superoxide anion and singlet molecular oxygen: their role in the microbicidal activity of the polymorphonuclear leukocyte. Biochem. Biophys. Res. Commun. 60: 909-917.

17. Lowry, O. H., N. J. Rosebrough, A. L. Farr, and R. J. Randall. 1951. Protein measurement with the Folin phenol reagent. J. Biol. Chem. 193: 265-275.

18. Curnutte, J. T., and B. M. Babior. 1975. Effects of anerobiosis and inhibitors on $\mathrm{O}_{2}^{-}$production by human granulocytes. Blood J. Hematol. 45: 851-861.
19. Holmes, B., A. R. Page, and R. A. Good. 1967. Studies of the metabolic activity of leukocytes from patients with a genetic ahnormality of phagocytic function. $J$. (lin. Invest. 46: 1422-1432.

20. Nathan, D. G., and R. L. Baehner. 1971. Disorders of phagocytic cell function. Prog. Hematol. 7: 235-254.

21. Stossel, T. P. 1974. Phagocytosis (3 prt. series). $N$ Engl. J. Med. 290: 717-723, 774-780, 833-839.

22. Cagan, R. H., and M. L. Karnovsky. 1964. Enzymatic basis of the respiratory stimulation during phagocytosis. Nature (Lond.). 204: 255-257.

23. Patriarca, P., R. Cramer, S. Moncalvo, F. Rossi, and D. Romeo. 1971. Enzymatic basis of metabolic stimulation in leukocytes during phagocytosis: the role of activated NADPH oxidase. Arch. Biochem. Biophys. $145: 255-262$.

24. Baehner, R. L., and M. L. Karnovsky. 1968. Deficiency of reduced nicotinamide-adenine dinucleotide oxidase in chronic granulomatous disease. Science (Wash. D.C.). $162: 1277-1279$.

25. Hohn, D. C., and R. I. Lehrer. 1975. NADPH oxidase deficiency in X-linked chronic granulomatous disease. J. Clin. Invest. 55: 707-713.

26. Nathan, D. G., R. L. Baehner, and D. K. Weaver 1969. Failure of nitro blue tetrazolium reduction in the phagocytic vacuoles of leukocytes in chronic granulomatous disease. J. Clin. Invest. 48: 1895-1904.

27. Gold, S. B., D. M. Hanes, D. P. Stites, and H. H. Fudenberg. 1974. Abnormal kinetics of degranulation in chronic granulomatous disease. N. Engl. J. Med. 291 : 332-337.

28. Curnutte, J. T., R. S. Kipnes, and B. M. Babior. 1975. A defect in pyridine nucleotide-dependent superoxide production by a particulate fraction from the granulocytes of patients with chronic granulomatous disease. N. Engl. J. Med. In press. 